\title{
Хірургія біліарних стриктур при хронічному панкреатиті
}

\begin{abstract}
Мета роботи: визначити оптимальні терміни виконання операції для профілактики біліарної стриктури при хронічному панкреатиті, оптимальний вид втручання на жовчних протоках, оптимальну комбінацію операції на жовчних протоках та на підшлунковій залозі, встановити показання для останніх.

Матеріали і методи. Ретроспективний аналіз історій хвороби пацієнтів, оперованих із діагнозом хронічний панкреатит з 2001 до 2020 р. Біліарні стриктури діагностували при механічній жовтяниці та при дилатації гепатикохоледоха $\geq 10$ мм. Біліарні стриктури підтверджували за допомогою інтраопераційної холангіографії. Виконували холедоходуоденостомію, гепатикоентеро-, холедохоентеростомію, трансдуоденальну папілосфінктеротомію, дуоденозберігальні резекції головки підшлункової залози. Ефективність операцій оцінена за відсутністю холангіту/механічної жовтяниці при спостереженні. Статистичний аналіз виконували з допомогою IBM SPSS Version27. Для аналізу категоріальних даних застосовували $\chi^{2}$ Пірсона, точний критерій Фішера. Рівень статистичної значущості встановлено на рівні $\mathbf{p}<0,05$.

Результати досліджень та їх обговорення. Відсутність рецидиву біліарних стриктур спостерігали у 85,7 \% пацієнтів. Рецидив біліарних стриктур (холангіт/жовтяниця) спостерігали у 8 пацієнтів (14,3 \%). Ознаки рецидиву виявлено: в групі, де використовували трансдуоденальну папілосфінктеротомію у 33,3 \%, у 16,7 \% пацієнтів з холедоходуоденостомію, у 9,7 \% хворих з дуоденозберігальними резекціями головки підшлункової залози. Щодо останніх, то цим хворим резекційну декомпресію доповнювали фенестрацією холедоха в резекційну порожнину. Біліарні стриктури спостерігали у 18,8 \% пацієнтів із тривалістю симптомів до 3 років та у 33,8 \% - більше 3 років.
\end{abstract}

Ключові слова: хронічний панкреатит; стеаторея; біліарна стриктура, біліарна гіпертензія; механічна жовтяниця.

Постановка проблеми і аналіз останніх досліджень та публікацій. При хронічному панкреатиті (ХП) паренхіма залози заміщається фіброзною рубцевою тканиною, яка може викликати компресію інтрапанкреатичної частини загальної жовчної протоки (ЗЖП). Псевдокісти, особливо розташовані в головці підшлункової залози (ПЗ), хоча і рідше, також можуть викликати стиснення та обструкцію ЗЖП. Клінічно біліарна стриктура (БС), або синонім даного терміну - біліарна гіпертензія (БГ), при ХП може проявлятися жовтяницею та/або холангітом. Інструментальні методи - ультразвукове дослідження (УЗД), комп'ютерна томографія (КТ), магнітнорезонансна холангіопанкреатографія (МРХПГ) виявляють розширення жовчних проток, а також допомагають провести диференціальний діагноз, зокрема зі злоякісними новоутвореннями періампулярної зони. Гіпербілірубінемія менш важлива у виявленні холестазу, особливо прихованого, порівняно з підвищенням рівня лужної фосфатази (ЛФ). У пацієнтів із ХП та персистуючим підвищенням ( $\geq 1$ місяця) ЛФ треба запідозрити БС та провести відповідні обстеження. Враховуючи можливий розвиток вторинного біліарного цирозу печінки в результаті тривалого холестазу, біліарну гіпертензію треба розцінювати як самостійне показання до відповідного втручання. Проте невирішеним є питання, чи вважати розширення ЗЖП $\geq 10$ мм у хворого на ХП без біохімічних ознак холестазу, ознакою бі- ліарною стриктури або фактором ризиком розвитку клінічно значущої БС у майбутньому?

БС може бути проявом занедбаності фіброзно-запального процесу в ПЗ, тому важливо не тільки правильно ії усунути, але й запобігти виникненню БС. Багато уваги в роботах останніх 5 років приділяється ендоскопічним методам лікування ХП, в тому числі і БС при ХП. При цьому є дані, що вказують на необхідність операції з приводу болю при ХП, після багатьох ендоскопічних втручань та нижчу ефективність таких операцій, оскільки процес у ПЗ стає більш занедбаним. Закономірно виникає питання - а чи потрібно зволікати з операцією у хворих на ХП? Чи потрібно виконувати багато стентувань при БС, замість операції, яка потенційно може розрішити як БС, так і дає змогу виконати патогенетичне втручання на ПЗ?

Різновиди можливих операцій з приводу БС мають свої недоліки та переваги щодо короткотривалих та довготривалих результатів, тому треба визначити найбільш оптимальний та універсальний метод.

Частота обструкції ЗЖП серед хворих на ХП варіює від 13 до 21 \% [1], що підкреслює актуальність проблеми.

Найбільша увага в недавніх дослідженнях приділена вибору стента - пластиковому чи металевому (SEMS), а у випадку останнього - стент покритий чи ні [2-7], також є окремі повідомлення про значно 


\section{З ДОСВІДУ РОБОТИ}

рідші причини БГ, такі як камінь головної панкреатичної протоки (ГПП), що став причиною біліарної обструкції [8]. Ступінь успіху (розрішення стриктури) та невдач (міграція стента, рецидив стриктури) і ускладнень варіює між дослідженнями. При використанні повністю покритого металевого стента (FCSEMS) - методу, що розглядається [2, 9] як такий, що дасть змогу позбутись недоліків притаманних пластиковим та непокритим металевим стентам (потреба багатьох повторних стентувань для пластикових [2] та проростання стента для непокритих SEMS [7]) у 123 пацієнтів із доброякісними БС в $81 \%$ випадків отримали розрішення стриктури, 3 них рецидив стриктури виник у 3 (10 \%) пацієнтів із ХП, розрішення стриктури у 27 (90 \%) хворих на ХП. Типовими ускладненням була міграція (9,7 \%), оклюзія (4,9 \%), холангіт (4,1 \%), гострий панкреатит (3,3 \%). Автори дійшли оптимістичного висновку, що хоча ХП є більш складною для стентування етіологією БС, більша тривалість знаходження стента може покращити рівень успіху процедури, але з застереженням, що опублікований високий рівень успіху був досягнутий завдяки тому, що центри дослідження були високопотоковими 3 наявністю досвідчених ендоскопістів [2]. Менш позитивний результат був отриманий при одноцентровому дослідженні FCSEMS - розрішення БС у 70,6 \% пацієнтів з ХП, невдачі були асоційовані з кальцинатами паренхіми ПЗ у 80 \% [10]. Місце стентування у лікуванні БС при ХП підсумовує міжнародний консенсус з інтервенційної ендоскопії при ХП - у пацієнтів зі значними кальцинатами та/або запальною масою в головці ПЗ, хірургічне лікування стриктури є методом вибору [11].

Значно менше робіт присвячено хірургічному лікуванню БС при ХП, зокрема порівнянню хірургічного методу та стентування $[12,13]$, але з важливим висновком мета-аналізу - у лікуванні БС, спричиненої ХП, хірургічне лікування може бути не тільки резервним методом після невдачі стентування, його можна розглядати як ефективний метод першої лінії, що позбавить пацієнта від багаторазових повторних ендоскопій [13].

Гіпотеза, що раннє хірургічне лікування в термін до 3 років тривалості симптомів $є$ вирішальним фактором контролю болю знайшла своє підтвердження в багатьох роботах [14-16]. Якщо вважати БС ознакою більш тяжкого захворювання [17], що спричиняється не тільки фіброзом тканин, які оточують холедох, а й псевдокістами та конкрементами ГПП [18], то можливо рання хірургія може покращити не тільки контроль болю, а й знизити ризик появи симптоматичної БС.

Біліарна стриктура в багатьох дослідженнях діагностується при розширенні ЗЖП $\geq 10$ мм у хворого на ХП при наявності біохімічних ознак холестазу впродовж місяця або більше [18], що вважається показанням для ендоскопічного або хірургічного її розрішення, через вірогідність розвитку вторинного біліарного цирозу печінки [19]. Водночас невідомо, чи вважати розширення ЗЖП $\geq 10$ мм при відсутності біохімічних ознак холестазу, приводом для відповідної симультанної операції з метою профілактики БС, під час виконання операції на ПЗ контролю болю? Розповсюдження неінвазійних інструментальних методів, таких як ендоскопічне УЗД та МРХПГ, виявило, що до 33 \% пацієнтів із дилатацією ЗЖП при нормальних рівнях печінкових ензимів має об’єктивну причину - холедохолітіаз, БС при хронічному панкреатиті, періампулярні дивертикули [20, 21].

У літературі часто використовується підсумування “хірургічне лікування”, хоча існує досить широкий арсенал операцій на жовчних шляхах при БС. В кожного з цих методів $є$ свої переваги та недоліки, співвідношення яких варіює між дослідженнями. Наприклад, деякі автори вважають гепатикоентеро-, холедохоентеростомію (ГЕА/ХЕА) “золотим стандартом” [22-24], тоді як інші вважають достатнім виконання холедоходуоденоанастомозу (ХДС) [25] або трансдуоденальної папілосфінктеропластики (ТДПСТ), які, у свою чергу, розцінюються як потенційна причина рецидивного холангіту та потенційний фактор ризику виникнення холангіокарциноми [26]. Широко відоме виконання фенестрації холедоха в резекційну порожнину, але деякі недавні дослідження показали високу частоту рецидиву біліарної обструкції при такій методиці [23]. Окрім визначення наявності переваг операційного лікування БС, треба встановити, чи всі методики будуть супроводжуватися такими перевагами однаковою мірою. Однією 3 раціональних запропонованих комбінацій [23, 24] $€$ операція Фрея та за необхідності - БДА.

Матеріали і методи. Проведений ретроспективний аналіз історій хвороби за період з 2001 до 2020 р. пацієнтів, оперованих із приводу ХП, а також з приводу ХП ускладненим БС. Критеріями діагностики останньої була клініка механічної жовтяниці та/або візуалізаційні дані за розширення гепатикохоледоха $\geq 10$ мм. ЛФ як рутинний тест у більшості хворих не виконували. За допомогою інтраопераційної холангіографії (IOXГ) через куксу жовчноміхурної протоки, до та після виконання ДЗРГПЗ або цистопанкреатоєностомії (ЦПЕА) при потраплянні контрасту в ДПК одразу, діагноз БС був виключений, при появі контрасту в ДПК після ДЗРГПЗ та ЦПЕА - БС вважалася розрішеною. Якщо втручання на ПЗ не було достатнім, 
виконувались операції на жовчних протоках. Пацієнтам високого ризику з коагулопатією та лабораторними ознаками печінкової недостатності виконували лише БДА, без втручання на ПЗ. Залежно від вищевказаних варіантів виконаних операцій сформовано групи пацієнтів: 1 - ТДПСТ з/ без втручань на П3; 2 - гепатикоентеро-, холедохоентеростомія (ГЕА/ХЕА); 3 - дуоденозберігальні резекції головки підшлункової залози (ДЗРГПЗ); 4 - холедоходуоденостомія. Окремо проаналізовано результати операцій пацієнтів із чітко встановленою тривалістю симптомів ХП (до 3 років “рання операція на ПЗ” або ж “рання хірургія” та після 3 років - “пізня операція на ПЗ”, відповідно “пізня хірургія”). Головним критерієм ефективності операцій була відсутність епізодів холангіту та або механічної жовтяниці при спостереженні. Діагностичними критеріями останніх були скарги на лихоманку, епізоди шкірного зуду, потемніння сечі, пожовтіння склер, виявлення лейкоцитозу $\geq 10 \times 10^{9}$ підвищення печінкових ензимів $\geq 2$ норм. Проводили опитування та періодичне обстеження хворих, оперованих до 2011 року - впродовж 2011 року, оперованих пізніше - через рік після операції. Статистичний аналіз виконували з допомогою IBM SPSS Version 27 (SPSS Inc, Чикаго, Іллінойс). Безперервні та категоріальні дані приведені як се- редні зі стандартними відхиленнями (СВ) та абсолютні/відносні частоти відповідно. Для аналізу категоріальних даних застосовували $\chi^{2}$ Пірсона, точний критерій Фішера. Рівень статистичної значимості встановлено на рівні р <0,05.

Результати досліджень та їх обговорення. При аналізі даних 147 пацієнтів, яким було виконано втручання на ПЗ (ДЗРГПЗ, панкреатоєюноанастомоз), БС у пацієнтів групи “рання хірургія” (74 особи) порівняно з пацієнтами групи “пізня хірургія” з клініко-лабораторними ознаками механічної жовтяниці була виявлена у 13 хворих (17,8 \% від групи) та у 17 хворих (23,9 \% від групи) відповідно; БС без механічної жовтяниці на момент госпіталізації спостерігали в одного хворого (1,4 \%) та 7 хворих (9,9 \%), відповідно, тобто підтверджена 3 допомогою IOХГ стриктура спостерігалася у 18,8 \% в групі “рання хірургія” та у 33,8 \% в групі “пізня хірургія”, p=0,04. Під час спостереження в обох групах нових випадків доброякісної БС не спостерігали.

При аналізі всіх хворих із попереднім діагнозом біліарна стриктура внаслідок ХП було ідентифіковано 61 хворого, 5 було виключено через підозру або встановлений пізніше злоякісний характер БС, залишилось 56. За даними таблиці 1 ,

Таблиця 1. Наявність жовтяниці та/або холангіту у віддаленному післяопераційному періоді залежно від операції на жовчних протоках

\begin{tabular}{|c|c|c|c|c|}
\hline \multicolumn{2}{|c|}{ Група } & \multirow{2}{*}{$\begin{array}{c}\begin{array}{c}\text { Відсутній рецидив } \\
\text { жовтяниці/ } \\
\text { холангіт }\end{array} \\
10(83,3 \text { \%) }\end{array}$} & \multirow{2}{*}{$\begin{array}{c}\begin{array}{c}\text { Рецидив } \\
\text { жовтяниці/ } \\
\text { холангіт }\end{array} \\
2 \text { (16,7 \%) }\end{array}$} & \multirow{2}{*}{$\begin{array}{c}\text { Всього } \\
12\end{array}$} \\
\hline Холедоходуоденостомія & Кількість (\% від групи) & & & \\
\hline & $\begin{array}{l}\text { \% від всіх хворих із } \\
\text { біліарними стриктурами }\end{array}$ & $17,9 \%$ & $3,6 \%$ & $21,4 \%$ \\
\hline \multirow{2}{*}{$\begin{array}{l}\text { Гепатикоентеро-, } \\
\text { холедохоентеростомія }\end{array}$} & Кількість (\% від групи) & $4(100,0 \%)$ & $0(0,0 \%)$ & 4 \\
\hline & $\begin{array}{l}\text { \% від всіх хворих із } \\
\text { біліарними стриктурами }\end{array}$ & $7,1 \%$ & $0,0 \%$ & $7,1 \%$ \\
\hline \multirow{2}{*}{$\begin{array}{l}\text { Трансдуоденальна } \\
\text { папілосфінктеротомія }\end{array}$} & Кількість (\% від групи) & $6(66,7 \%)$ & $3(33,3$ \%) & 9 \\
\hline & $\begin{array}{l}\text { \% від всіх хворих із } \\
\text { біліарними стриктурами }\end{array}$ & $10,7 \%$ & $5,4 \%$ & $16,1 \%$ \\
\hline \multirow{2}{*}{$\begin{array}{l}\text { Дуоденозберігальні } \\
\text { резекції підшлункової } \\
\text { залози }\end{array}$} & Кількість (\% від групи) & $28(90,3 \%)$ & $3(9,7 \%)$ & 31 \\
\hline & $\begin{array}{l}\text { \% від всіх хворих із } \\
\text { біліарними стриктурами }\end{array}$ & $50,0 \%$ & $5,4 \%$ & $55,4 \%$ \\
\hline \multicolumn{2}{|l|}{ Кількість (\%) всього } & $48(85,7 \%)$ & $8(14,3 \%)$ & 56 \\
\hline
\end{tabular}

Примітка. Різниця між групами статистично не достовірна (p>0,05). 


\section{З ДОСВІДУ РОБОТИ}

напади холангіту або жовтяниці спостерігали у 8 пацієнтів (14,3 \%). Найгірші результати у групі ТДПСТ - у 3 з 9 хворих (у 33,3 \%) спостерігали ознаки рецидиву, холангіт виникав у 2 (16,7 \%) 3 12 хворих з ХДС, а також у 3 (9,7 \%) з 31 хворого, яким виконували ДЗРГПЗ. В останньому випадку, цим трьом хворим резекційна декомпресія була доповнена фенестрацією холедоха в резекційну порожнину через наявне, але слабке потрапляння контрасту в ДПК при IOХГ. За співвідношенням кальцинатів паренхіми, конкрементів ГПП, наявністю запальної маси в головці ПЗ (діаметр головки П3 $\geq 4$ см) та наявністю або відсутністю рецидивів жовтяниці/холангіту за групами - статистично достовірних відмінностей не було (p>0,05).

Було два летальні випадки: один хворий, у якого операція Фрея була доповнена ХДС - помер від печінково-ниркової недостатності, один хворий, якому була виконана тільки ДЗРГПЗ - помер від внутрішньочеревної кровотечі. 3 ранніх післяопераційних ускладнень відмічені: в одного хворого з групи ДЗРГПЗ - внутрішньочеревинна кровотеча, зупинена шляхом релапаротомії та гемостазу, часткова неспроможність БДА у 2 хворих з ХДС, та в одного хворого з ГЕА/XЕА - лікування консервативне, жовчні нориці закрились самостійно (середня тривалість нориці 7 днів, СВ 2). За ранніми післяопераційними ускладненнями групи статистично достовірно не відрізнялись ( $>0,05)$.

Успіх хірургічного лікування (відсутність рецидиву) біліарної стриктури досягнутий у 85,7 \%, що є зіставним із даними інших авторів [13, 22]. Враховуючи відсутність рецидиву у пацієнтів з гепатикоентеро-, холедохоентероанастомозами, рівень успіху міг би бути ще кращий при рутинному виконанні такого варіанту БДА у всіх хворих. Ми не спостерігали розвитку холангіокарциноми у пацієнтів, в яких було виконано ТДПСТ або ХДС, але в цих пацієнтів була досить висока частота виникнення холангіту та або жовтяниці, навіть вищий за літературні дані - в нашій серії 33,3 \% та 16,7 \%, відповідно, проти 11,3 \% та 10,9 \% відповідно [26]. Цікавим є випадок одного з пацієнтів, якому була виконана операція Фрея у комбінації 3 ТДПСТ у 2011 році. Впродовж спостереження у даного хворого виник рецидив БС, що проявлявся спочатку рецидивуючим холангітом, а згодом і стриктурою Фатерова сосочка з епізодами холедохолітіазу, що потребували у подальшому 4 ендоскопічні папілосфінктеротомії з літоекстракцією. Згодом, у 2021 р. хворому було виконано гепатикоентероанастомоз з петлею тонкої кишки, що була використана раніше для ПЕА.

Ми не встановили статистично достовірного взаємозв’язку рецидиву біліарної стриктури та кальцинатів головки ПЗ, конкрементів ПЗ, запальної маси в головці до операції, що свідчить на користь хірургічного лікування БС при наявності таких факторів, які, у свою чергу, є доведеними факторами ризику невдачі ендоскопічного стентування [10, 11].

Автори вважають надійним методом виконання IOXГ як для підтвердження наявності БС, так і для визначення необхідності додавання до ДЗРГПЗ гепатикоентеро- або холедохоентероанастомозу. Декомпресія інтрапанкреатичної частини холедоха шляхом висічення запальної маси була достатньої для 28 (90,3 \%) з 31 пацієнтів, щоб відбулося потрапляння контрасту у ДПК, ознак рецидиву БС у цих пацієнтів не спостерігалось. Тому ми підтримуємо методологію та висновки Merdrignac з соавт., та Ray, S з соавт. [24, 23] які опублікували схожий підхід.

Дослідження, присвячені терміну захворювання як вирішальному фактору контролю болю та збереження функції ПЗ [14, 27], не розглядали вірогідність розвитку ускладнень з боку навколишніх органів, таких як біліарна стриктура. Ми встановили статистично достовірний взаємозв'язок тривалості симптомів ХП більше 3 років та більшою частотою БС. Враховуючи що у пацієнтів, оперованих до 3 років з початку симптомів, без БС на момент операції, ми не спостерігали її виникнення у подальшому, можна вважати, що рання операція при ХП може також запобігти розвитку локальних ускладнень.

Висновки. 1. Розвиток біліарної стриктури при ХП у нашому дослідженні був пов'язаний 3 терміном захворювання - при тривалості захворювання більше 3 років частота виникнення стриктури була статистично достовірно вищою. Це може свідчити на користь “ранньої” операції при ХП, без довготривалого консервативного лікування, таким чином запобігаючи виникненню такого ускладнення, як БС.

Дилатація ЗЖП $\geq 10$ мм за даними абдомінальної візуалізації є достатнім приводом для того, щоб запідозрити БС та відповідно перевірити їі наявність та потребу у її корекції з допомогою IОХГ.

За наявності запальної маси або псевдокісти в головці ПЗ достатньо для їі усунення може бути виконання ДЗРГПЗ, зокрема операції Фрея, якщо за даними IOXГ зовнішня декомпресія холедоха не була достатньою, найкращою операцією є виконання гепатикоентеро- або холедохоентероанастомозу з тією ж петлею тонкої кишки за Ру, що й для панкреатоентероанастомозу.

При відсутності запальної маси в головці також доцільно комбінувати ПЕА з ГЕА/ХЕА. Такі 
методи, як ХДС, ТДПСТ та фенестрація холедоха в резекційну порожнину при виконанні ДЗРГПЗ, супроводжуються вищою частотою холангіту та рецидиву жовтяниці, хоча ця різниця і не була статистично достовірною в даному досліджені.

\section{СПИСОК ЛІТЕРАТУРИ}

1. Ma M. X. Benign biliary strictures: Prevalence, impact, and management strategies / M. X. Ma, V. Jayasekeran, A. K. Chong // Clin. Exp. Gastroenterol. - 2019. - Vol. 12. - P. 83-92.

2. A us multicenter study of safety and efficacy of fully covered self-expandable metallic stents in benign extrahepatic biliary strictures / P. Saxena, D. L. Diehl, V. Kumbhari [et al.] // Dig. Dis. Sci. - 2015. - Vol. 60 (11). - P. 3442-3448.

3. Seicean A. Endoscopic therapy in chronic pancreatitis: Current perspectives / A. Seicean, S. Vultur // Clin. Exp. Gastroenterol. - 2015. - Vol. 8. - P. 1-11.

4. International consensus statements for endoscopic management of distal biliary stricture / Y. Nakai, H. Isayama, H. P. Wang [et al.] // J. Gastroenterol. Hepatol. - 2020. - Vol. 35 (6). P. 967-979.

5. Leong R. W. Metallic stents for Benign extrahepatic biliary stricture: In praise of Self-Expansion? / R. W. Leong // Dig. Dis. Sci. - 2015. - Vol. 60 (11). - P. 3158-3159.

6. Efficacy of multiple biliary stenting for refractory benign biliary strictures due to chronic calcifying pancreatitis / H. Ohyama, R. Mikata, T. Ishihara [et al.] // World J. Gastrointest. Endosc. 2017. - Vol. 9 (1). - P. 12-18.

7. Bartel M. J. The status of sems versus plastic stents for benign biliary strictures / M. J. Bartel, J. T. Higa, J. L. Tokar // Curr. Gastroenterol. Rep. - 2019. - Vol. 21 (7). - P. 29.

8. Pancreatic calculus causing biliary obstruction: Endoscopic therapy for a rare initial presentation of chronic pancreatitis / A. J. Shetty, C. G. Pai, S. Shetty, G. Balaraju // Dig. Dis. Sci. 2015. - Vol. 60 (9). - P. 2840-2843.

9. Randomized multicenter study of multiple plastic stents vs. covered self-expandable metallic stent in the treatment of biliary stricture in chronic pancreatitis / C. Haapamäki, L. Kylänpää, M. Udd [et al.] // Endoscopy. - 2015. - Vol. 47 (7). - P. 605-610. 10. Fully covered Self-expandable metal stents in biliary strictures caused by chronic pancreatitis not responding to plastic stenting: a prospective study with 2 years of follow-up / V. Perri, I. Boškoski, A. Tringali [et al.] // Gastrointest. Endosc. - 2012. Vol. 75 (6). - P. 1271-1277.

11. International consensus guidelines on Interventional endoscopy in chronic pancreatitis. Recommendations from the working group for the international consensus guidelines for chronic pancreatitis in collaboration with the International Association OF Pancreatology, the American pancreatic Association, the Japan Pancreas society, and European pancreatic club / M. Kitano, T. M. Gress, P. K. Garg [et al.] // Pancreatology. - 2020. - Vol. 20 (6). - P. 1045-1055.

12. Udd M. The role of Endoscopic and surgical treatment in chronic pancreatitis / M. Udd, L. Kylänpää, A. Kokkola // Scand. J. Surg. - 2020. - Vol. 109 (1). - P. 69-78.

13. Meta-analysis of the long term success rate of different inter-
Перспективи подальших досліджень. Біліарні стриктури при хронічному панкреатиті є дуже поширеним ускладенням. В цьому сенсі актуальним є виконання хірургічного втручання на ранній стадії захворювання, що може запобігти розвитку біліарних стриктур.

ventions in benign biliary strictures / O. Huszár, B. Kokas, P. Mátrai [et al.] // PloS One. - 2017. - Vol. 12 (1). - e0169618.

14. Effect of early surgery vs endoscopy-first approach on pain in patients with chronic pancreatitis / Y. Issa, M. A. Kempeneers, M. J. Bruno [et al.] // JAMA. - 2020 - Vol. 323 (3). - P. 237-247. 15. Surgery for chronic pancreatitis / C. J. Yang, L. A. Bliss, S. D. Freedman [et al.] // Pancreas. - 2015. - Vol. 44 (5). P. 819-823.

16. Surgery in chronic pancreatitis: indication, timing and procedures / S. A. W. Bouwense, M. A. Kempeneers, H. C. Santvoort [et al.] // Visc. Med. - 2019. - Vol. 35 (2). - P. 110-118.

17. Influence of bile duct obstruction on the results of Frey's procedure for chronic pancreatitis / F. Cauchy, J. M. Regimbeau, D. Fuks [et al.] // Pancreatology. - 2014. - Vol. 14 (1). - P. 21-26. 18. Incidence and significance of biliary stricture in chronic pancreatitis patients undergoing extracorporeal shock wave lithotripsy for obstructing pancreatic duct stones / J. J. Hyun, S. S. Irani, A. S. Ross [et al.] // Gut. Liver. - 2021. - Vol. 15 (1). - P. 128-134. 19. Chronic pancreatitis. nature reviews disease primers / J. Kleeff, J. P. Neoptolemos, J. Muñoz [et al.] // Nat. Rev. Dis. Primers. - 2017. - Vol. 3 (1). - P. 17060.

20. Smith I. Incidentally identified common bile duct dilatation / I. Smith, K. Monkemuller, C. M. Wilcox // J. Clin. Gastroenterol. - 2015. - Vol. 49 (10). - P. 810-815.

21. Endoscopic ultrasound in common bile duct dilatation with normal liver enzymes / C. D. Angelis, M. Marietti, M. Bruno [et al.] // World J. Gastrointest. Endosc. - 2015. - Vol. 7 (8). P. 799-805.

22. Surgical management of benign biliary stricture in chronic pancreatitis: a single-center experience / S. Ray, S. Ghatak, K. Das [et al.] // Indian J. Surg. - 2015. - Vol. 77 (S2). - P. 608613.

23. Frey procedure combined with biliary diversion for the treatment of chronic pancreatitis-related biliary obstruction: impact of the types of diversion / S. Ray, K. Das, K. Jana [et al.] // World J. Surg. - 2020. - Vol. 44 (7). - P. 2359-2366.

24. Frey procedure combined with biliary diversion in chronic pancreatitis / A. Merdrignac, D. Bergeat, M. Rayar [et al.] // Surgery. - 2016. - Vol. 160 (5). - P. 1264-1270.

25. Choledochoduodenostomy: is it really so bad? / W. M. I. Leppard, T. M. Shary, D. B. Adams, K. A. Morgan // J. Gastrointest. Surg. - 2011. - Vol. 15 (5). - P. 754-757.

26. Late development of bile duct cancer in patients who had Biliary-Enteric drainage for benign disease: a follow-up study of more than 1,000 patients / A. Tocchi, G. Mazzoni, G. Liotta [et al.] // Ann. Surg. - 2001. - Vol. 234 (2). - P. 210-214.

27. Earlier surgery improves outcomes from painful chronic pancreatitis / N. Ke, D. Jia, W. Huang, Q. M. Nunes [et al.] // Medicine. - 2018. - Vol. 97 (19). - e0651. 


\section{З ДОСВІДУ РОБОТИ}

\section{REFERENCES}

1. Ma, M.X., Jayasekeran, V., \& Chong, A.K. (2019). Benign biliary strictures: Prevalence, impact, and management strategies. Clin. Exp. Gastroenterol., 12, 83-92. DOI: 10.2147/CEG. S165016.

2. Saxena, P., Diehl, D.L., Kumbhari, V., Shieh, F., Buscaglia, J.M., Sze, W., ..., \& Khashab, M.A. (2015). A us multicenter study of safety and efficacy of fully covered self-expandable metallic stents in benign extrahepatic biliary strictures. Dig. Dis. Sci., 60 (11), 3442-3448. DOI: 10.1007/s10620-015-3653-5.

3. Seicean, A., \& Vultur, S. (2015). Endoscopic therapy in chronic pancreatitis: current perspectives. Clin. Exp. Gastroenterol., 8, 1-11. DOI: 10.2147/CEG.S43096.

4. Nakai, Y., Isayama, H., Wang, H.P., Rerknimitr, R., Khor, C., Yasuda, I., ..., \& Devereaux, B. (2020). International consensus statements for endoscopic management of distal biliary stricture. J. Gastroenterol. Hepatol., 35 (6), 967-979. DOI: 10.1111/ jgh.14955.

5. Leong, R.W. (2015). Metallic stents for Benign extrahepatic biliary stricture: in praise of self-expansion? Dig. Dis. Sci., 60 (11), 3158-3159. DOI: 10.1007/s10620-015-3705-x.

6. Ohyama, H., Mikata, R., Ishihara, T., Sakai, Y., Sugiyama, H., Yasui, S., \& Tsuyuguchi, T. (2017). Efficacy of multiple biliary stenting for refractory benign biliary strictures due to chronic calcifying pancreatitis. World J. Gastrointest. Endosc., 9 (1), 12-18. DOI: 10.4253/wjge.v9.i1.12.

7. Bartel, M.J., Higa, J.T., \& Tokar, J.L. (2019). The status of sems versus plastic stents for benign biliary strictures. Curr. Gastroenterol. Rep., 21 (7), 29 DOI: 10.1007/s11894-019-0696-3.

8. Shetty, A.J., Pai, C.G., Shetty, S., \& Balaraju, G. (2015). Pancreatic calculus causing biliary obstruction: Endoscopic therapy for a rare initial presentation of chronic pancreatitis. Dig. Dis. Sci., 60 (9), 2840-2843. DOI: 10.1007/s10620-015-3670-4.

9. Haapamäki, C., Kylänpää, L., Udd, M., Lindström, O., Grönroos, J., Saarela, A., ..., \& Halttunen, J. (2015). Randomized multicenter study of multiple plastic stents vs. covered self-expandable metallic stent in the treatment of biliary stricture in chronic pancreatitis. Endoscopy, 47 (7), 605-610. DOI: 10.1055/s-00341391331.

10. Perri, V., Boškoski, I., Tringali, A., Familiari, P., Mutignani, M., Marmo, R., \& Costamagna, G. (2012). Fully covered Self-expandable metal stents in biliary strictures caused by chronic pancreatitis not responding to plastic stenting: a prospective study with 2 years of follow-up. Gastrointest. Endosc., 75 (6), 1271-1277. DOI: 10.1016/j.gie.2012.02.002.

11. Kitano, M., Gress, T.M., Garg, P.K., Itoi, T., Irisawa, A., Isayama, H., ..., \& Whitcomb, D.C. (2020). International consensus guidelines on interventional endoscopy in chronic pancreatitis. Recommendations from the working group for the international consensus guidelines for chronic pancreatitis in collaboration with the International Association OF Pancreatology, the American pancreatic Association, the Japan Pancreas society, and European pancreatic club. Pancreatology, 20 (6), 1045-1055. DOI: 10.1016/j.pan.2020.05.022.

12. Udd, M., Kylänpää, L., \& Kokkola, A. (2020). The role of endoscopic and surgical treatment in chronic pancreatitis. Scand. J. Surg., 109 (1), 69-78. DOI: 10.1177/1457496920910009.

13. Huszár, O., Kokas, B., Mátrai, P., Hegyi, P., Pétervári, E., Vincze, Á., ..., \& Szücs, Á. (2017). Meta-analysis of the long term success rate of different interventions in benign biliary strictures.
PloS One, 12 (1), e0169618.

14. Issa, Y., Kempeneers, M.A., Bruno, M.J., Fockens, P., Poley, J.W., Ahmed Ali, U., ..., \& Boermeester, M.A. (2020). Effect of early surgery vs endoscopy-first approach on pain in patients with chronic pancreatitis. JAMA, 323 (3), 237-247. DOI: 10.1001/ jama.2019.20967.

15. Yang, C.J., Bliss, L.A., Freedman, S.D., Sheth, S., Vollmer, C.M., Ng, S.C., ..., \& Tseng, J.F. (2015). Surgery for chronic pancreatitis. Pancreas, 44 (5), 819-823. DOI: 10.1097/ MPA.0000000000000333.

16. Bouwense, S.A.W., Kempeneers, M.A., van Santvoort, H.C., Boermeester, M.A., van Goor, H., \& Besselink, M.G. (2019). Surgery in chronic pancreatitis: indication, timing and procedures. Visc. Med., 35 (2), 110-118. DOI: 10.1159/000499612.

17. Cauchy, F., Regimbeau, J.M., Fuks, D., Balladur, P., Tiret, E., \& Paye, F. (2014). Influence of bile duct obstruction on the results of Frey's procedure for chronic pancreatitis. Pancreatology, 14 (1), 21-26. DOI: 10.1016/j.pan.2013.10.008.

18. Hyun, J.J., Irani, S.S., Ross, A.S., Larsen, M.C., Gluck, M., \& Kozarek, R.A. (2021). Incidence and significance of biliary stricture in chronic pancreatitis patients undergoing extracorporeal shock wave lithotripsy for obstructing pancreatic duct stones. Gut. Liver, 15 (1), 128-134. DOI: 10.5009/gnl19380.

19. Kleeff, J., Neoptolemos, J.P., Muñoz, J., Akisik, F., Rebours, V., Drewes, A.M., ..., \& Neoptolemos, J.P. (2017). Chronic pancreatitis. Nat. Rev. Dis. Primers., 3 (1), 17060. DOI: 10.1038/ nrdp.2017.60.

20. Smith, I., Monkemuller, K., \& Wilcox, C.M. (2015). Incidentally identified common bile duct dilatation. J. Clin. Gastroenterol., 49 (10), 810-815. DOI: 10.1097/MCG.0000000000000394.

21. De Angelis, C., Marietti, M., Bruno, M., Pellicano, R., \& Rizzetto, M. (2015). Endoscopic ultrasound in common bile duct dilatation with normal liver enzymes. World J. Gastrointest. Endosc., 7 (8), 799-805. DOI: 10.4253/wjge.v7.i8.799.

22. Ray, S., Ghatak, S., Das, K., Dasgupta, J., Ray, S., Khamrui, S., ..., \& Das, S. (2015). Surgical management of benign biliary stricture in chronic pancreatitis: a single-center experience. Indian J. Surg., 77 (S2), 608-613. DOI: 10.1007/s12262-013-0940-2.

23. Ray, S., Das, K., Jana, K., Das, R., Kumar, D., \& Khamrui, S. (2020). Frey procedure combined with biliary diversion for the treatment of chronic pancreatitis-related biliary obstruction: Impact of the types of diversion. World J. Surg., 44 (7), 2359-2366. DOI: 10.1007/s00268-020-05465-7.

24. Merdrignac, A., Bergeat, D., Rayar, M., Harnoy, Y., Turner, K., Courtin-Tanguy, L., ..., \& Sulpice, L. (2016). Frey procedure combined with biliary diversion in chronic pancreatitis. Surgery, 160 (5), 1264-1270. DOI: 10.1016/j.surg.2016.05.006. 25. Leppard, W.M., Shary, T.M., Adams, D.B., \& Morgan, K.A. (2011). Choledochoduodenostomy: Is it really so bad? J. Gastrointest. Surg., 15 (5), 754-757. DOI: 10.1007/s11605-011-1465-2. 26. Tocchi, A., Mazzoni, G., Liotta, G., Lepre, L., Cassini, D., \& Miccini, M. (2001). Late development of bile duct cancer in patients who had Biliary-Enteric drainage for benign disease: A follow-up study of more than 1,000 patients. Ann. Surg., 234 (2), 210-214. DOI: 10.1097/00000658-200108000-00011.

27. Ke, N., Jia, D., Huang, W., Nunes, Q.M., Windsor, J.A., Liu, X., \& Sutton, R. (2018). Earlier surgery improves outcomes from painful chronic pancreatitis. Medicine, 97 (19). DOI: 10.1097/MD.0000000000010651. 


\title{
З ДОСВІДУ РОБОТИ
}

\author{
V. G. YARESHKO, YU. O. MIKHEIEV, V. D. SKRYPKO, O. F. SHPYLENKO
}

Zaporizhia Medical Academy of Post-Graduate Education

\section{SURGERY FOR BILIARY STRICTURE IN CHRONIC PANCREATITIS}

The aim of the work: to determine the optimal timing of surgery to prevent biliary stricture (BS) in chronic pancreatitis (CP), the optimal type of intervention in the bile ducts, the optimal combination of surgery on the bile ducts and pancreas and to establish indications for the latter.

Materials and Methods. Retrospective analysis of case histories of patients who were operated due to chronic pancreatitis from 2001 to 2020. Diagnostic criteria of BS were mechanical jaundice and/or dilatation of of the hepatic choledochus $\geq 10$ mm. BS was confirmed by intraoperative cholangiography. Choledochoduodenostomy, hepatic and choledochoenterostomy, transduodenal papillosphincterotomy, duodenum-preserving resections of the pancreatic head were performed. The effectiveness of operations assessed by the absence of cholangitis/mechanical jaundice during observation. Statistical analysis was performed using IBM SPSS Version27. Pearson's $\chi^{2}$, Fisher's exact criterion was used to analyze categorical data. The level of statistical significance is set at $\mathrm{p}<0.05$.

Results and Discussion. No recurrence of BS achieved in $85.7 \%$ of patients. Recurrence of BS (cholangitis/jaundice) was observed in 8 patients (14.3\%). Signs of recurrence were found: in the group of transduodenal papillosphincterotomy in $33.3 \%$, in $16.7 \%$ of patients with choledochoduodenostomy, in $9.7 \%$ of patients with duodenum-preserving resections of the pancreatic head . For the latter, resection decompression was supplemented in these patients by fenestration of the choledochus into the resection cavity. BS was observed in $18.8 \%$ of patients with symptoms lasting up to 3 years and in $33.8 \%$ - more than 3 years.

Key words: chronic pancreatitis; steatorrhea; biliary stricture, biliary hypertension; mechanical jaundice. 